\section{Comment}

The number of requests for euthanasia or physician assisted suicide increased in the first decade of registration in the Netherlands, but from 1995 onwards stabilised at about 5000 requests per year. The increase probably reflected the process of liberalisation in the early years, boosted by broad publicity on lawsuits and the foundation of the Dutch Society for Voluntary Euthanasia. Mainly due to the activities of this society the number of living wills has increased substantially over the years.

The importance of pain in such requests decreased significantly, paralleled by a proportional increase in the importance of deteriorating health. Improvements in pain management and the increasing importance of feelings like self esteem are obvious reasons for these changes. ${ }^{4}$ Over the past decades the willingness of both physicians and the general public in the Netherlands to accept E/PAS has increased. This attitude resulted in the acceptance of a law tolerating $\mathrm{E} / \mathrm{PAS}$ performed in compliance with strict regulations. ${ }^{5}$ Some people feared that the lives of increasing numbers of patients would end through medical intervention, without their consent and before all palliative options were exhausted. Our results, albeit based on requests only, suggest that this fear is not justified.

We thank the general practitioners from the Dutch Sentinel Network for their invaluable contributions over the years and Marianne Heshusius for her secretarial support.

Contributors: RLM was responsible for the overall conduct of the study and for writing the paper. $\mathrm{AB}$ initiated the survey and is guarantor. GJV was responsible for data analysis. PS undertook the statistical analysis. LP was the data manager.

Funding: None.

Competing interests: None declared.

Ethical approval: The ethical committees of the Dutch General Practitioners Association and NIVEL approved the investigation.

Hughes J. Consequentialism and the slippery slope: a response to Clark. JAppl Philos 2000;17:213-9.

2 Onwuteaka-Philipsen BD, Van der Heide A, Koper D, Keij-Deerenberg I, Rietjens JAC, Rurup ML, et al. Van der Maas PJ, van de Wal G, Havekate I, de Graaff CLM, Kester JGC, Onwuteaka-Philipsen BD, et al. Euthanasia, and other end-of-life decisions in the Netherlands 1990, 1995, and 2001. Lancet http://image.thelancet.com/extras/03art3297web.pdf (accessed 26 Jun 2003).

De Wit MA, Koopmans MP, Kortbeek LM, van Leeuwen NJ, Bartelds AI, van Duynhoven YT. Gastroenteritis in sentinel general practices, the Netherlands. Emerg Infect Dis 2001;7:82-91.

4 Lavery JV, Boyle J, Dickens BM, Maclean H, Singer PA. Origins of the desire for euthanasia and assisted suicide in people with HIV-1 or AIDS: a qualitative study. Lancet 2001:358:362-7.

5 Thynne K. Implications of legalising euthanasia in the Netherlands: greater regulatory control? J Law Med 2002;10:232-8. (Accepted 6 June 2003)

\title{
National survey of medical decisions at end of life made by New Zealand general practitioners
}

\author{
Kay Mitchell, R Glynn Owens
}

Department of Psychology, University of Auckland, Private Bag 92019, Auckland, New Zealand

Kay Mitchell research fellow

University of Wales, Bangor, Gwynedd LL57 2AS

R Glynn Owens professor of forensic clinical psychology

Correspondence to:

K Mitchell

k.mitchell@ auckland.ac.nz

BMJ 2003;327:202-3
Several attempts have been made in New Zealand to liberalise laws prohibiting euthanasia. Surveys in other countries where legalisation of euthanasia was being considered have found illegal provision of physician assisted death. ${ }^{1-3}$ However, none of these studies investigated the availability of palliative care services, which arguably make euthanasia unnecessary. ${ }^{4}$ We investigated the prevalence of physician assisted death in New Zealand within the context of availability of palliative care services.

\section{Participants, methods, and results}

We obtained an English version of the anonymous questionnaire previously used in Dutch and Australian studies $^{13}$ and sent it to 2602 general practitioners. The general practitioners were in a commercially supplied address list, comprising $87 \%$ of the general practitioners in New Zealand in 2000. To retain consistency with previous studies, we sought details of medical decisions made for the last death attended in the preceding 12 months.

Of 1302 returned questionnaires, 1255 were usable. An interdisciplinary palliative care team was available in $1116(89 \%)$ cases. Eleven hundred (88\%) doctors reported attending a death in the past 12 months, and $693(63 \%)$ had made a medical decision that could hasten death (table).
In $39(5.6 \%)$ cases, death was attributed to actions consistent with physician assisted suicide or euthanasia. In 17 of these cases there was no discussion with the patient, and in $34(87 \%)$ palliative care services were available (table). The doctor alone administered the drug in 13 cases, the nurse alone in 15 cases, the patient alone in two cases, and more than one person in eight cases; no information was available for one case.

Ninety four respondents $(13.6 \%)$ reported final actions that were taken partly with the intent of hastening death. Fifty (53\%) had not discussed this with the patient beforehand. A further 132 (19\%) had withdrawn or withheld treatment explicitly to hasten death, $63(48 \%)$ without discussion with the patient. Palliative care was available in over $85 \%$ of cases. Other actions were defensible under the principle of double effect-withholding or withdrawing treatment (55) or increasing medication to alleviate symptoms (373) knowing that death could be hastened (table).

Providers of physician assisted death were significantly older and less religious than those who had made other medical decisions. No other significant demographic differences were noted.

\section{Comment}

Thirty nine respondents had provided some form of physician assisted death, and 226 had taken actions 
Medical actions that could hasten death taken by 693 New Zealand general practitioners on behalf of last dying patient cared for in past 12 months

\begin{tabular}{|c|c|c|c|c|c|c|}
\hline & No $(\%)$ of actions ${ }^{*}$ & $\begin{array}{l}\text { No (\%) of last } \\
\text { actions before } \\
\text { death }\end{array}$ & $\begin{array}{c}\text { No }(\%) \text { who had } \\
\text { palliative care } \\
\text { team available }\end{array}$ & $\begin{array}{c}\text { No }(\%) \text { who had } \\
\text { not discussed with } \\
\text { patient } \dagger\end{array}$ & $\begin{array}{l}\text { No (\%) of patients } \\
\text { not fully competent } \\
\text { to discuss } \ddagger\end{array}$ & $\begin{array}{l}\text { No (\%) of patients } \\
\text { competent to } \\
\text { discuss } \neq\end{array}$ \\
\hline \multicolumn{7}{|c|}{ Probability that end of life hastened by: } \\
\hline Withholding a treatment & $258(37.2)$ & $28(4.0)$ & $26(93)$ & $15(54)$ & $13(87)$ & $2(13)$ \\
\hline Withdrawing a treatment & $200(28.9)$ & $27(3.9)$ & $25(93)$ & $16(59)$ & $13(81)$ & $1(6)$ \\
\hline $\begin{array}{l}\text { Intensifying alleviation of } \\
\text { pain or symptoms }\end{array}$ & $588(84.8)$ & $373(53.8)$ & $339(91)$ & $219(59)$ & $133(61)$ & $71(32)$ \\
\hline $\begin{array}{l}\text { Intention of intensifying } \\
\text { relief of pain or symptoms } \\
\text { was partly to end life }\end{array}$ & $172(24.8)$ & $94(13.6)$ & $80(85)$ & $50(53)$ & $42(84)$ & $7(14)$ \\
\hline \multicolumn{7}{|c|}{ Action with explicit purpose of not prolonging life or hastening death: } \\
\hline Withholding a treatment & $130(18.8)$ & $75(10.8)$ & $69(92)$ & $38(51)$ & $32(84)$ & $6(16)$ \\
\hline Withdrawing a treatment & $71(10.2)$ & $57(8.2)$ & $53(93)$ & $25(44)$ & $22(88)$ & $1(4)$ \\
\hline $\begin{array}{l}\text { Supplying or administering } \\
\text { drug to cause death }\end{array}$ & $39(5.6)$ & $39(5.6)$ & $34(87)$ & $17(44)$ & $16(94)$ & 0 \\
\hline
\end{tabular}

${ }^{\star}$ More than one could be answered.

†Percentage based on number of last actions.

‡Percentage based on number who had not discussed action with patient. Not all general practitioners replied.

partly or explicitly with the intention of hastening death. These actions would be indefensible under the principle of double effect. ${ }^{5}$ Our figures could be an underestimate of the number of physician assisted deaths as the phrasing of the question asked only about the last death attended. The fact that euthanasia is illegal in New Zealand could also have contributed to the low response rate $(48 \%){ }^{2}$

Our results are consistent with research elsewhere. $^{1-3}$ The proportion of physician assisted deaths in which there was no prior discussion with the patient was higher than reported in the Netherlands, ${ }^{1}$ but similar to that in Belgium and Australia.. ${ }^{23}$

The intent to hasten death does not seem to be a consequence of the non-availability of palliative care. This suggests that palliative care did not meet patients' needs. We do not know whether this is because the best palliative care was not available or because even best care was insufficient to meet patients' needs. Either way, New Zealand requires greater commitment to the provision of quality palliative care or a re-examination of the legal framework that surrounds decision making at the end of life, or both.

Contributors: KM was the principal investigator of the study, which formed part of her PhD. RGO supervised the study. KM is guarantor.

Funding: None.

Competing interests: None declared.

Ethical approval: University of Auckland Human Subjects Ethics Committee, 10.02.00, Ref. 1999/Q032.

1 Van der Maas PJ, van Delden JIM, Pijnenborg L. Euthanasia and other medical decisions concerning the end of life. Health Policy 1992;22(special issue): $1-2$

2 Deliens L, Mortier F, Bilsen J, Cosyns M, Vander Stichele R, Vanoverloop $\mathrm{J}$, et al. End-of-life decisions in medical practice in Flanders, Belgium: a nationwide survey. Lancet 2000;356:1806-11.

Kuhse H, Singer P, Baume P, Clark M, Rickard M. End-of-life decisions in Australian medical practice. Med J Aust 1997;166:191-6.

4 Zylicz Z. Ethical considerations in the treatment of pain in a hospice environment. Patient Educ Counsel 2000;41:47-53.

5 Gillett GR. Intent in law and medicine. N Z Law J 1991 April:115-21.

(Accepted 4 July 2003)

\section{A good death?}

My father's death was all set to be the best a hospital could offer. He'd been virtually bed-bound in hospital for the past 10 months, and everyone who worked on his ward knew him and knew what was happening. Everyone agreed that he should not be resuscitated in the event of cardiorespiratory arrest, and eventually we asked that he should no longer be given antibiotics in the event of infection. It was suggested that it was the excellent standard of nursing that had kept him alive so much longer than his body seemed to desire.

The medical team got used to him taking up one of their precious beds and came to see that, as his condition deteriorated, he was unlikely to reach a nursing home. The nursing staff treated him well. The family waited 10 long months for him to die. We all knew the score.

The fateful day approached, and the clans gathered. I drove back early from a holiday in the Lake District, my brother flew home from overseas. As respiratory distress took hold, the morphine drip was set and my father gradually slipped into comfortable oblivion. We spent 48 hours by his bed waiting for that final moment of release.

But my father's last few minutes coincided with the early morning nursing handover, and just as he took his final breath, the nurse who'd known him longest came back to work after three days off. Just before "handover" she popped in behind the curtains of his cubicle, took one look at his colour and slapped a pulse oximeter on him. On finding it recorded no oxygen saturation, she fled in search of another that "worked." Not surprisingly, this too failed. She then dragged in the resuscitation trolley. In shock, I asked her what she was doing.

"He's stopped breathing," she observed. Then she burst into tears, leaving the family to comfort her.

Abi Berger science editor, BMJ 